\title{
Klasyfikacja modeli biznesowych w Industry 4.0
}

\author{
Prof. dr hab. Jerzy Niemczyk iD \\ Uniwersytet Ekonomiczny we Wrocławiu \\ Katedra Strategii i Metod Zarządzania
}

Dr Rafał Trzaska

Uniwersytet Ekonomiczny we Wrocławiu

Katedra Strategii i Metod Zarządzania

\section{Industry 4.0 z perspektywy ekonomii i nauk o zarządzaniu}

W kontekście systemów gospodarowania nauka ekonomii zajmowała się dotychczas przede wszystkim zdefiniowaniem celu gospodarowania, a nauki o zarządzaniu wyborem sposobów osiągania tych celów. Wokół tych pytań w ekonomii i zarządzaniu toczy się dyskusja.

Dotychczas obowiązującym optymalnym sposobem rozwiązania tych problemów było przedsiębiorstwo zorientowane na maksymalizację zysku. Ten model organizacji procesu gospodarowania jest modelem przyjętym w ekonomii klasycznej i neoklasycznej. Przedsiębiorstwo z tej perspektywy jest rozumiane jako zbiór zasobów poddawanych procesom optymalizacji. W naukach o zarządzaniu ten nurt badawczy określany jest mianem podejścia zasobowego.

Jeśli przyjmiemy takie rozumienie przedsiębiorstwa, to technologie Industry 4.0 przede wszystkim poszerzają zbiór zasobów materialnych i niematerialnych stanowiących firmę i zmieniają hierarchię ich wartości. Mogą zatem poszerzyć możliwości optymalizacji.

O takich możliwościach piszą między innymi Hecklaua, Galeitzkea, Flachsa i Kohlb. Stwierdzili oni, że:

[...] firmy muszą radzić sobie ze skróconym czasem wprowadzania produktów na rynek, krótszymi cyklami życia produktów oraz potrzebą obniżenia kosztów, aby pozostać konkurencyjnym [...]. Klasyczne modele biznesowe stają się łatwo podatne 
na substytuty, firmy muszą usprawnić swoje procesy innowacyjne i przekształcić swój model biznesowy na bardziej zorientowany na usługi $[\ldots]^{1}$.

W tym samym artykule autorzy ci sugerują, że „firmy będą potrzebować nowych pracowników, do bardziej strategicznych, wymagających większej koordynacji i bardziej odpowiedzialnych zadań”2. Podobne spostrzeżenia można odnaleźć w pracy Transforming to a hyper-connected society and economy - towards an Industry 4.0. Jej autorzy zauważają, że technologie $4.0 \mathrm{w}$ zasadzie nie wskazują na nowe możliwości działania, a jedynie są narzędziami pozwalającymi rozwiązać problemy zarządzania w nowych warunkach działania globalnych i międzybranżowych sieci - problemy, których nie można rozwiązać klasycznymi narzędziami ekonomii i zarządzania ${ }^{3}$. Te obserwacje wskazują na wciąż tradycyjny sposób postrzegania firmy i jej zagadnień optymalizacyjnych. Technologie Industry $4.0 \mathrm{w}$ tej perspektywie mogą jedynie oddziaływać na tradycyjne nośniki wartości, takie jak ekonomia skali czy ekonomia zakresu.

Większy potencjał wykorzystania technologii z rodziny Industry 4.0 otrzymamy, gdy do opisu firmy przyjmiemy logikę teorii agencji, ekonomii kosztów transakcyjnych, bliskie teoriom neoinstytucjonalnym. Jeśli uznamy, że przedsiębiorstwo jest zbiorem kontraktów z interesariuszami przedsiębiorstwa, to otrzymamy inny przedmiot działań optymalizacyjnych. A gdy dodatkowo przyjmiemy, że technologie 4.0 pozwolą na zrezygnowanie $\mathrm{z}$ koncepcji projektowania przedsiębiorstwa w układzie hierarchicznym i umożliwią skuteczne zarządzanie na bazie jednorazowych kontraktów, to otrzymamy zupełnie nową jakościowo organizację.

Jeszcze inne możliwości analizy otrzymamy, jeśli uznamy za podstawowe w definiowaniu przedsiębiorstwa poglądy ekonomistów austriackich. Z perspektywy ekonomii austriackiej może okazać się, że prakseologiczne ujęcie ludzkiego działania jako działania celowego, przy użyciu technologii 4.0, może doprowadzić nas do zupełnie innej logiki komponowania całości organizacyjnego działania, niż ta sformułowana przez Smitha i Ricardo. A wtedy już blisko do rozwiązań rodem $\mathrm{z}$ teorii złożoności.

W podobnym układzie jak w tabeli 1 można przedstawić nurty badawcze nauk o zarządzaniu. Do analizy wybrano nurt zasobowy, nurt sieciowy i nurt teorii złożoności.

1 F. Hecklau i wsp., Holistic approach for human resource management in Industry 4.0, „Procedia Cirp" 2016, no. 54, s. 1-6.

2 Tamże.

3 W. Bauer i wsp., Transforming to a hyper-connected society and economy - towards an „Industry 4.0”, „Procedia Manufacturing” 2015, no. 3, s. 417-424. 
Tabela 1. Industry 4.0 a możliwości rozwiązywania problemów firmy z perspektywy wybranych nurtów ekonomii

\begin{tabular}{|l|l|}
\hline Perspektywa badawcza & Możliwości rozwiązania problemów firmy z użyciem technologii 4.0 \\
\hline Ekonomia klasyczna & $\begin{array}{l}\text { Klasyczne problemy firmy rozwiązywane przy użyciu nowych } \\
\text { technologii lub nowe problemy firmy rozwiązywane przy użyciu } \\
\text { nowych technologii }\end{array}$ \\
\hline $\begin{array}{l}\text { Neoinstytucjonalne } \\
\text { teorie ekonomii }\end{array}$ & Nowe problemy rozwiązywane przy użyciu nowych technologii \\
\hline Ekonomia austriacka & Nowe problemy rozwiązywane przy użyciu nowych technologii \\
\hline
\end{tabular}

Źródto: opracowanie własne.

Logika nurtu zasobowego jest zbliżona interpretacyjnie do klasycznej i neoinstytucjonalnej koncepcji przedsiębiorstwa. Tutaj również ujmujemy przedsiębiorstwo jako zbiór zasobów albo zbiór kontraktów i oczekujemy od kierujących zarządzania zmierzającego do optymalnego wykorzystania zasobów z uwagi na cel rozumiany jako maksymalizacja zysku lub maksymalizacja wartości. W tym kontekście możemy jednoznacznie stwierdzić, że Industry 4.0 umożliwia lepsze, optymalne wykorzystanie zasobów.

Logika nurtu sieciowego pozwala na szersze spojrzenie na możliwości Industry 4.0. Wynika to chociażby z faktu, że niektóre renty ekonomiczne nurtu sieciowego nie mogą być osiągnięte bez nowych technologii. Dotyczy to nadwyżki wynikającej z efektu sieciowego, nadwyżki wynikającej z efektu „długiego ogona”, a szczególnie nadwyżki uzyskiwanej z efektu chmury wartości, o której pisze Falencikowski.

Największe możliwości wykorzystania Industry 4.0 związane są z nurtem badawczym wskazującym na użycie w budowaniu systemów zorganizowanego działania rozwiązań z zakresu teorii złożoności. Badania w tym zakresie dotyczą przede wszystkim teorii systemów samoorganizujących się, teorii chaosu, ścieżki zależności (path dependence), złożonych systemów adaptacyjnych czy modelowania opartego na koncepcjach agentów. Badania te szeroko recenzują Rokita i Dziubińska w pracy Systemy złożone w zarzadzaniu 5 . Możliwości wykorzystania teorii złożoności w zarządzaniu sygnalizowane były już na początku XX wieku. Jednak podjęte wtedy próby sprowadzały się do wnioskowania na podstawie analogii niż właściwego dla teorii złożoności wnioskowania dedukcyjnego na bazie logiki matematycznej, matematyki i statystyki. Ciekawą propozycją w tym zakresie są rozważania odwołujące się do koncepcji ewolucyjnych i teorii gier, zawarte w pracy

4 T. Falencikowski, Istota chmury wartości - założenia podstawowe, „Prace Naukowe Wałbrzyskiej Wyższej Szkoły Zarządzania i Przedsiębiorczości” 2015, nr 32, s. 121-129.

5 J. Rokita, A. Dziubińska, Systemy złożone w zarzqqdzaniu, „Prace Naukowe Uniwersytetu Ekonomicznego w Katowicach”, Wydawnictwo Uniwersytetu Ekonomicznego, Katowice 2016. 
Model DNA firmy 6 . Odszukiwanie zachowań opisywanych językiem dedukcji, a nie empirii może rzeczywiście służyć bardziej precyzyjnemu poznaniu świata organizacji. Warunkiem jest posiadanie praktycznie pełnego zbioru danych. Pojawienie się wraz z Industry 4.0 możliwości gromadzenia i przetwarzania ogromnych zbiorów danych sprawiło, że możliwe, ale i konieczne stało się modelowanie zachowań organizacji na podstawie równań nieliniowych. Według Bosserta i Desmeta w sytuacji, którą dają nam wybrane technologie 4.0, możliwe jest, zamiast budowania zhierarchizowanych i procesowo ustawionych organizacji, projektowanie organizacji modułowych, opartych na platformach IT, integrujących działania niezależnie od hierarchii. Te rozwiązania szybciej się uczą, lepiej skalują, są nie tyle elastyczne, ile samokonfigurujące się?.

Tabela 2. Industry 4.0 a możliwości rozwiązywania problemów firmy z perspektywy wybranych nurtów nauk o zarządzaniu

\begin{tabular}{|l|l|}
\hline Perspektywa badawcza & Możliwości rozwiązania problemów firmy z użyciem technologii 4.0 \\
\hline Podejście zasobowe & $\begin{array}{l}\text { Klasyczne problemy firmy rozwiązywane przy użyciu nowych } \\
\text { technologii lub nowe problemy firmy rozwiązywane przy użyciu } \\
\text { nowych technologii }\end{array}$ \\
\hline Podejście sieciowe & Nowe problemy rozwiązywane przy użyciu nowych technologii \\
\hline Teorie złożoności & $\begin{array}{l}\text { Nowe, przyszłe problemy rozwiązywane przy użyciu nowych } \\
\text { technologii }\end{array}$ \\
\hline
\end{tabular}

Źródło: opracowanie własne.

Wskazane perspektywy badawcze ekonomii i nauk o zarządzaniu dają szerokie możliwości skorzystania z efektów wdrożenia rozwiązań Industry $4.0 \mathrm{w}$ procesach zarządzania na wszystkich jego poziomach. Te nowe rozwiązania pozwalają na wdrożenia zmian o charakterze ilościowym (szybciej, taniej i elastycznej), ale przede wszystkim na wdrożenie zmian radykalnie przekształcających organizacje oraz na realny rozwój organizacji. Autorzy wspomnianego raportu firmy McKinsey zadają sobie pytanie, które można potraktować jako wniosek wynikający z przedstawionych w tej części analiz - „pytanie nie brzmi, jak szybko firmy technologiczne staną się firmami samochodowymi, ale jak szybko staniemy się firmą technologiczną" $"$.

6 L. Czarnecki, Model DNA firmy, „Monografie i Opracowania Uniwersytetu Ekonomicznego we Wroctawiu" 2015, nr 252.

7 D. Barton, D. Court, Three keys to building a data-driven strategy, www.mckinsey.com/business-functions/mckinsey-digital/our-insights/three-keys-to-building-a-data-driven-strategy (dostęp: 22.12.2019).

8 Tamże. 
W tym kontekście warto chyba dostrzec niewykorzystane możliwości historycznego nurtu zarządzania wiedzą. Rozwijany na przełomie wieków, szczególnie w zarządzaniu, sygnalizował możliwości uczenia się organizacji. Niestety, teoria wyprzedziła tutaj praktykę. Dopiero teraz, wraz z pojawieniem się możliwości technologicznych, jest w pełni możliwe budowanie wartości w wyniku połączeń, odrzucenie hierarchii na rzecz mobilności, a umowy o pracę na rzecz kontraktu, budowanie innowacji w wyniku współpracy, a nie procesowo - wewnątrz hierarchii, działania proaktywne zamiast reaktywnych czy wykorzystanie wprost systemów Business Intelligence w działaniu systemów zorganizowanych ${ }^{9}$.

Celem przedstawionych w tej części analiz było wprowadzenie pewnych ram do rozważań nad generalnym problemem modelu biznesowego (rodzajów i typów) dla Industry 4.0. Przedstawione propozycje będą wykorzystane w dalszej części do klasyfikowania modeli biznesowych w nurcie 4.0.

\section{Ogólna definicja modelu biznesowego w kontekście Industry 4.0}

Model biznesowy jest kategorią nauki i praktyki biznesu, do której roszczą pretensje naukowcy prowadzący zarówno badania w dyscyplinie ekonomii, jak i w naukach o zarządzaniu. Dlatego, żeby dokładniej podać jego wyznaczniki w warunkach Industry 4.0, należało wcześniej zakreślić ramy Industry 4.0 z perspektywy ekonomii i zarządzania, co uczyniono w części pierwszej.

W większości prac dotyczących Industry 4.0 przyjęto, że jest to termin określający czwartą rewolucję, sprowadzającą się nie tyle do zmian związanych z cyfryzacją, bo takie zmiany już generowała trzecia rewolucja, ile do zmian związanych z pełną sieciową możliwością wykorzystania cyfryzacji. Jest to zatem rewolucja wprowadzająca myślenie perspektywą logiki cyfrowej do wszystkich kontekstów działania wszystkich typów organizacji, w tym organizacji przemysłowej. Na pewno przyczyni się to zatem do powstania nowych rodzajów i typów modeli biznesowych. Dla potrzeb niniejszego opracowania przyjęto, że ten podstawowy zbiór technologii 4.0 tworzyć będą:

1. Inteligentne czujniki to technologia i urządzenia, które odbierają dane ze środowiska fizycznego i, dzięki wbudowanej logice, przetwarzają dane lokalnie.

2. Cloud Computing to technologia, która pozwala na szybki i elastyczny dostęp do dużych zasobów obliczeniowych przez Internet, bez konieczności budowania infrastruktury informatycznej i zarządzania nią.

9 E. Mercier-Laurent, Innovation ecosystems, John Wiley \& Sons, New York 2013. 
3. Digitalizacja to technologia, która w swej istocie odnosi się do przechwytywania danych analogowych i kodowania ich do formatu, który może być przechowywany, przetworzony i przesłany przez komputery.

4. Cyberbezpieczeństwo i ochrona to technologie ochrony systemów komputerowych przed kradzieżą lub uszkodzeniem sprzętu, ochrony przed hakowaniem oprogramowania lub danych elektronicznych, a także ochrony przed zakłóceniem lub niewłaściwym kierowaniem świadczonych przez nich usług.

5. Urządzenia mobilne to technologie i urządzenia przenośne zdolne do przetwarzania informacji.

6. Blockchain to technologia bezpiecznego cyfrowego rejestru transakcji, pierwotnie używana do rejestrowania transakcji dokonywanych za pomocą kryptowalut, takich jak Bitcoin [...].

7. Internet rzeczy (IoT) to technologia, która składa się z czujników, sterowników i inteligentnych urządzeń komercyjnych lub przemysłowych, które przesyłają dane przez Internet. Niektóre z tych urządzeń mogą akceptować polecenia i wykonywać funkcje zdalnie [...].

8. Pojazdy autonomiczne [...].

9. Rzeczywistość wirtualna i rozszerzona to technologie interaktywnego doświadczenia rzeczywistego lub wirtualnego środowiska, w którym obiekty są ulepszane przez generowane komputerowo informacje percepcyjne, czasem w wielu modalnościach sensorycznych, w tym wizualnych, słuchowych, dotykowych, somatosensorycznych i węchowych.

10. Rozpoznawanie obrazu to systemy kamer o wysokiej rozdzielczości i często wysokiej trwałości wyposażone w funkcję rozpoznawania obrazów oparte na algorytmach uczenia maszynowego i sztucznej inteligencji.

11. Robotyzacja i automatyzacja to technologie i urządzenia obejmujące stopniowe wdrażanie maszyn w celu wykonywania żmudnych i powtarzalnych operacji, zarówno w biurze, jak i na miejscu produkcji ${ }^{10}$.

W literaturze przedmiotu te wymienione technologie najczęściej wypełniają zakres pojęciowy sformułowania rewolucja cyfrowa. Spotkamy też termin digitalizacja, który ujmuje inteligentny proces biznesowy tworzący wartość, wykorzystujący technologie informacyjne i komunikacyjne, takie jak duże zbiory danych, przetwarzanie w chmurze i urządzenia mobilne, Internet przedmiotów i oprogramowanie sieci społecznościowych. W rezultacie digitalizacja oznacza nie tylko dostarczanie informacji, ale także reprezentację procesów tworzenia wartości w formie elektronicznej11.

10 J. Niemczyk i wsp., Scalability 4.0 as Economic Rent in Industry 4.0, „Transformations in Business \& Economics" 2019, no. 18.

11 R. Schmidt i wsp., Industry 4.0-potentials for creating smart products: empirical research results, [w:] International Conference on Business Information Systems, Springer, Cham 2015, s. 16-27. 
W publikacjach nie odnajdziemy zbyt wielu definicji modeli biznesowych dedykowanych Industry 4.0. Większość definicji modelu biznesowego z prac badawczych z lat 2000-2019 ujmuje model biznesowy z perspektywy podejścia zasobowego. Nawet najpopularniejszy model biznesowy - Osterwaldera i Pigneura - odwołuje się do kluczowych zasobów, kluczowych działań i kluczowych partnerów organizowanych ze względu na kryterium wartości oczekiwanej, generowanej dla klienta, czyli do elementów wyróżnionych w podejściu zasobowym. Wśród koncepcji modeli biznesowych, które moglibyśmy zakwalifikować jako bliższe współczesnym trendom w ekonomii i naukach o zarządzaniu, spotkamy na przykład stwierdzenia, że modele biznesowe dla Industry 4.0 będą koncentrować się na usprawnianiu klasycznego łańcucha wartości poprzez poprawienie automatyzacji i zwiększenie efektywności operacyjnej, umożliwiające zoptymalizowanie struktury ${ }^{12}$. Takiemu rozumieniu modelu bliżej jest zatem do strategii wzrostu niż rozwoju ${ }^{13}$.

Inne definicje modelu biznesowego wskazują na tworzenie wartości z wygenerowanych danych ${ }^{14}$, a jeszcze inne na konkretne wykorzystanie w budowaniu wartości danego, wybranego rodzaju technologii 4.0 .

Kolejne definicje modeli biznesowych, bliskie rozwiązaniom 4.0, koncentrują się na tworzeniu wartości dodanej z sieci wartości, rozumianej przeważnie jako kontraktowanie określonych wartości. W tych ujęciach bardzo często inaczej ujmowany jest cel gospodarowania. Często nie jest to już prosto zdefiniowany cel w postaci oczekiwanego poziomu zysku lub oczekiwanej wartości dla akcjonariuszy, ale trudna do zdefiniowania wartość ekosystemu, rozumianego jako dostosowanie pomiędzy firmą a interesariuszami (aktorami) ekosystemu ${ }^{15}$ oraz tworzenie wartości w ekosystemie i jej przechwytywanie ${ }^{16}$. W znacznym zakresie modele biznesowe odwołujące się do sieci różnią się od klasycznych ujęć zasobowych tym,

12 C. Burmeister, D. Lüttgens, F.T. Piller, Business model innovation for Industrie 4.0: why the "Industrial Internet” mandates a new perspective on innovation, „Die Unternehmung” 2016, vol. 70(2), s. 124-152; H. Kagermann i wsp., Recommendations for implementing the strategic initiative INDUSTRIE 4.0: Securing the future of German manufacturing industry, final report of the Industrie 4.0 Working Group, Forschungsunion, 2013.

13 Porównaj rozważania: M. Czarnecki, Rozwój organizacyjny a problemy wzrostu przedsiębiorstw, Wydawnictwo Difin, Warszawa 2016.

14 H. Kagermann i wsp., Recommendations...; M.E. Porter, J.E. Heppelmann, How smart, connected products are transforming competition, „Harvard Business Review” 2014, vol. 92(11), s. 64-88.

15 M.G. Jacobides, C. Cennamo, A. Gawer, Towards a theory of ecosystems, „Strategic Management Journal" 2018, vol. 39(8), s. 2255-2276.

16 K. Möller, A. Halinen, Managing business and innovation networks - From strategic nets to business fields and ecosystems, „Industrial Marketing Management” 2017, no. 67, s. 5-22. 
że dotyczą również innych zasad konstruowania zorganizowanego działania. Tutaj odniesieniem nie jest już klasyczny zbiór zasobów w mniejszym lub większym stopniu zdematerializowanych, w większym lub mniejszym stopniu obciążonych prawem własności, ale zbiór działań bazujących na transakcjach opisanych językiem ekonomii współdzielenia, koncepcją chmury wartości, ideą komponowania biznesu wokół platformy informatyczno-informacyjnej lub schematami mentalnymi z teorii złożoności.

Ten przegląd propozycji ujęć modelu biznesowego pokazuje, że to, co może zaproponować rewolucja cyfrowa, to wykorzystanie cyfrowego modelu biznesowego odniesionego przede wszystkim do innego ujmowania kluczowej kategorii obecnej w teoriach kosztów transakcyjnych, w ujęciu sieciowym i teorii złożoności, jaką jest transakcja.

Podstawą przyjętego w tym opracowaniu sposobu definiowania modelu biznesowego będzie koncepcja cyfrowego modelu biznesowego odniesionego do jednostki analizy, jaką jest transakcja. Będzie się ona opierać na sześciu kluczowych elementach: systemie zawierania transakcji, cyfrowym systemie oferenta (podaż), cyfrowym systemie kupującego (popyt), cyfrowym systemie zarządzania efektywnością, cyfrowym systemie zliczającym (pieniężnym lub niepieniężnym) i założeniu o powtarzalności transakcji ${ }^{17}$.

Operowanie jednostką analizy w postaci transakcji pozwoli, w opinii autorów, na inne spojrzenie na możliwości modeli biznesowych - bardziej rewolucyjne niż w podejściu sieciowym. Dzięki takiej analizie zbiór obiektów mogących być poddawanymi optymalizacji zwiększy się wielokrotnie (da to możliwość skorzystania z teorii złożoności), wzrosną również możliwości tworzenia wartości na bazie samej transakcji, chociażby poprzez wyeliminowanie pośredników.

W literaturze przedmiotu odnajdziemy podobne rozwiązania pod hasłem model biznesowy serwitalizacji cyfrowej. Cyfrowa serwitalizacja definiowana jest jako przejście do inteligentnych systemów usług produktowych, które umożliwiają tworzenie i wychwytywanie wartości poprzez monitorowanie, kontrolę, optymalizację i autonomicznie realizowane funkcje. Aby zyskać na wartości dzięki cyfrowej serwitalizacji, firmy muszą skorzystać z trzech wymiarów ofert cyfrowych (tj. produktów, usług i oprogramowania), które powinny ze sobą współpracować ${ }^{18}$. Tak więc znowu okazuje się, że kluczową kategorią będzie tutaj transakcja.

17 R.C. Härting, C. Reichstein, M. Schad, Potentials of Digital Business Models - Empirical investigation of data driven impacts in industry, „Procedia Computer Science” 2018, no. 126, s. $1495-1506$.

18 A.G. Frank i wsp., Servitization and Industry 4.0 convergence in the digital transformation of product firms: A business model innovation perspective, „Technological Forecasting and Social Change" 2019, no. 141, s. 341-351. 
Aby model biznesowy mógł być uznany za model Industry 4.0, musi spełnić następujące warunki:

- musi łączyć na zasadzie serwitalizacji dotychczasowe sposoby generowania wartości;

- musi łączyć w taki sposób, by zapewniać możliwość generowania różnych strumieni wartości;

- musi łączyć różne sposoby generowania wartości na podstawie jednolitego protokołu komunikacji;

- musi łączyć strumienie wartości (transakcje łączenia) poprzez eliminowanie wszystkich nośników kosztów transakcyjnych;

- musi generować wartość w obrębie całego ekosystemu;

- a wszystkie te procesy łączenia muszą się odbywać z wykorzystaniem technologii Industry 4.0 .

\section{Typy i klasyfikacje modeli biznesowych w Industry 4.0}

W literaturze przedmiotu można odnaleźć wiele klasyfikacji modeli biznesowych przedstawionych przez różnych badaczy. Klasyfikacje te lokują się w trzech kierunkach myślenia, jakie możemy obserwować w budowaniu modeli biznesowych.

W pierwszym z kierunków badacze wykorzystują model biznesowy jako abstrakcyjną koncepcję do bardzo ogólnego sposobu opisania tworzenia, sprzedaży i dostarczania wartości klientom ${ }^{19}$. Drugi z kierunków charakteryzuje się naciskiem na identyfikację struktury modelu biznesu. Autorzy tego podejścia przedstawiają listę niezbędnych elementów modelu biznesowego ${ }^{20}$. Trzeci z kierunków badania modeli biznesowych skupia się na konkretnej sytuacji i analizuje modele biznesowe realnych firm. Naukowcy wykorzystują tutaj model biznesowy do opisywania i analizowania firm odnoszących sukcesy.

Ten ogólny obraz koncepcji budowania modeli biznesowych jest w znacznym stopniu wykorzystywany przy identyfikacji rodzajów i typów modeli dla gospodarki 4.0. Autorzy tego opracowania dokonali przeglądu literatury w obszarze klasyfikacji modeli biznesowych Industry 4.0. Przeglądowi poddano literaturę z baz

19 G. Chesbro, Open business model. IP-Management, Generation, 2008, s. 352; C. Markides, The new business model: strategy of painless innovation The new business model: strategy of painless innovation, Alpina Publisher, Moscow 2010, s. 298; A. Osterwalder, I. Pine, Building of business models, Alpina Publisher Series, Skolkovo, Moscow, 2013.

20 A.J. Slywotzky, Migration values. What will happen to your business the day after tomorrow, Mann, Ivanov and Ferber, Moscow 2006. 
danych SCOPUS, ScienceDirect i JSTOR. Przegląd ograniczono do literatury powstałej po 2011 roku (termin oficjalnego powstania Industry 4.0), a także dotyczącej zarządzania i hasła business model industry 4.0. Wyniki wyszukiwania pozwoliły zlokalizować 70 artykułów, z których 17 poddano analizie. Część tych badań stanowiła podstawę konstrukcji tego opracowania. Obecne w literaturze przedmiotu klasyfikacje modeli biznesowych autorzy pogrupowali w czterech podstawowych grupach modeli, wyróżnionych ze względu na dominującą logikę przyjętą $\mathrm{w}$ danej klasyfikacji. W opracowaniu przyjęto klasyfikacje modeli biznesowych Industry 4.0 na:

- klasyfikacje oparte na danych;

- klasyfikacje oparte na inteligentnym produkcie i usłudze (product-service systems);

- klasyfikacje oparte na pozornie nieskalowanych działaniach;

- klasyfikacje oparte na strategiach nowoczesnej konkurencji rynkowej.

\section{Modele biznesowe Industry 4.0 oparte na danych}

Dane określane są mianem złota XX wieku. To dzięki nim można uzyskać niewidoczną, ale znaczącą przewagę nad konkurencją. Jednak i same dane mogą być źródłem wartości. Od lat danymi zajmują się giganci technologiczni - Google, Apple i Microsoft - i małe start-upy, które rozpoczynają swoją przygodę z biznesem. Najlepszym chyba przykładem nastawienia firmy na wykorzystanie danych są transakcje fuzji i przejęć, między innymi zakup przez Google firmy Boston Dynamic. W 2013 roku Google zainwestowało w start-up MIT o nazwie Boston Dynamic (BD), chcąc budować wspólnie pierwsze humanoidalne roboty. Z czasem okazało się, że istotniejszym zasobem będą dane. W 2017 roku Google sprzedało firmę Boston Dynamic firmie SoftBank Group z Chin, pozostawiając sobie zarządzanie danymi oraz algorytmy uczenia się, a wyzbywając się tylko sprzętu ${ }^{21}$.

W tym samym kierunku idą sugestie formułowane przez firmę doradczą McKinsey. Proponuje ona uwzględnić w budowaniu strategii kontekst danych, wskazując, że przy wyborze strategii warto zastanowić się nad: wybraniem poprawnych danych, budowaniem modeli, które przewidują i optymalizują wyniki biznesowe, a także możliwościami zmienienia swojej firmy poprzez opracowanie analiz biznesowych, które można wykorzystać w czasie rzeczywistym, czy osadzenia analityki w prostych narzędziach, które może wykorzystać każdy w firmie ${ }^{22}$.

21 Boston Dynamics, www.bostondynamics.com (dostęp: 20.12.2019).

22 D. Barton, D. Court, Three keys... 
Dowodem na konieczność traktowania danych jako zasobu strategicznego są też możliwości Business Intelligence - technologii bliskiej 4.0. BI pozwala na sterowanie zdarzeniami w czasie rzeczywistym, natychmiastowy dostęp do danych na każdym szczeblu zarządzania, prowadzenie analiz predykcyjnych, interaktywną wizualizację, intuicyjne interfejsy wspomagane semantycznym wyszukiwaniem oraz powszechny i mobilny dostęp do danych ${ }^{23}$. A wszystko to można uczynić, ucząc się na zbiorach danych.

W literaturze przedmiotu trudno odnaleźć klasyfikacje modeli biznesu oparte na danych będących efektem pracy badawczej. Stąd w tym miejscu wykorzystane zostaną informacje pozyskane z bloków tematycznych, które obecne są w internecie w postaci dostępnej, ale nierecenzowanej wiedzy.

Jedna z propozycji klasyfikacji modeli biznesowych opartych na danych zbudowana została jako piramida wzrostu dostarczanej wartości i wysiłku wymaganego do otrzymania rezultatów (rysunek 1). Podstawą piramidy jest model danych traktowanych jako usługa (data as a services). Następnym poziomem jest informacja jako usługa (information as a services), a ostatnim postrzeganie odpowiedzi jako usługi (answers as a services).

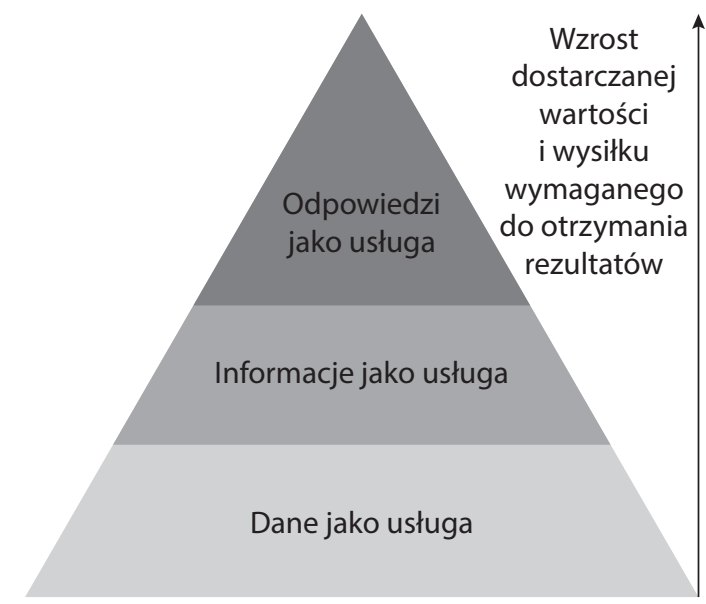

Rysunek 1. Trzy podstawowe modele biznesowe dużych zbiorów danych i ich wartość Źródto: Exploring big data business models \& the winning value propositions behind them, www.businessmodelsinc.com/big-data-business-models/ (dostęp: 29.12.2019).

Model Dane jako usługa (DaaS) skupia się na zapewnieniu sposobu do wydobycia z danych własnych spostrzeżeń. DaaS opiera się na propozycji wartości w postaci

23 H. Dudycz, Mapa pojęć jako wizualna reprezentacja wiedzy ekonomicznej, „Monografie i Opracowania Uniwersytetu Ekonomicznego we Wrocławiu” 2013, nr 229, s. 213. 
dostarczania dużych ilości przetwarzanych danych z myślą, że nasz klient będzie świadczył na bazie tych danych usługi dla swoich klientów. Klientami w tym przypadku mogą być dostawcy rozwiązań, którzy chcą wykorzystać dane zbliżone do surowych, w celu polepszenia własnej oferty. Dane w tym modelu biznesowym pochodzą od własnych klientów firmy lub ze źródeł zewnętrznych (od kluczowych partnerów) i są agregowane zgodnie z zaleceniami dostawców rozwiązań. W tym modelu biznesowym działalnością budującą wartość jest przetwarzanie danych w taki sposób, aby były one pozbawione wrażliwych danych klientów. Przykładami organizacji korzystających z tego modelu biznesowego są otwarte witryny rządowe, takie jak datasf.org, oraz dostawcy komercyjni, między innymi Gnip, Twitter, Bloomberg, Factual, Socrata, Zephyr Health, Axciom, Experian, Sift Science, BlockScore, Climate Corp, Epsilon, People Lookup, PIPL, Intelius, ZabraSearch ${ }^{24}$.

Model biznesowy Informacje jako usługa (IaaS) koncentruje się na zapewnianiu pełniejszej informacji na podstawie analizy przetwarzanych danych. W przeciwieństwie do modelu biznesowego DaaS, który polega na agregowaniu i rozpowszechnianiu wielu przetwarzanych danych dla klientów w celu tworzenia własnych propozycji wartości, model biznesowy IaaS polega na przekształcaniu danych w informacje dla klientów, którzy czegoś potrzebują i są skłonni zapłacić za bardziej dopasowane dane. Przykładami organizacji działających w takim modelu mogą być HERE i FitBit 25 .

Model biznesowy Odpowiedź jako usługa (AssS) koncentruje się na udzielaniu odpowiedzi na konkretne pytania, a nie tylko na sprzedaży informacji, które można wykorzystać do uzyskania odpowiedzi. Klienci AaaS często potrzebują określonego wskazania, aby podejmować decyzje. W rzeczywistości w tym przypadku mogą być oni skłonni do podejmowania spontanicznych decyzji o „zakupie”, biorąc pod uwagę odpowiednią propozycję wartości (uzyskaną odpowiedź). Kluczowa dla tego modelu biznesowego jest zdolność firmy do tworzenia prawdziwej, zaufanej wartości w odpowiedziach udzielanych klientom. Klienci z kolei będą generować większą wartość i wiarygodność otrzymanych dóbr. Przykładem organizacji działającej w takim modelu jest Mint, usługa zarządzania osobistymi pieniędzmi (online i aplikacja) ${ }^{26}$.

W publikacji Big data business models: challenges and opportunities Schroeder wyróżnia pięć klasyfikacji modeli biznesowych opartych na danych ${ }^{27}$ :

24 Exploring big data business models \& the winning value propositions behind them, www.businessmodelsinc.com/big-data-business-models/ (dostęp: 29.12.2019).

25 Tamże.

26 Tamże.

27 R. Schroeder, Big data business models: Challenges and opportunities, „Cogent Social Sciences" 2016, vol. 2(1). 
- model Informowanie o decyzjach biznesowych (Informing business decisions) - w modelu tym dane zbierane wewnętrznie w organizacji pomagają podejmować decyzje; w takich przypadkach dane są wykorzystywane jako dane wejściowe w procesie zarządzania; w najbardziej zaawansowanych organizacjach dane własne są wykorzystywane do informowania wewnętrznych decydentów biznesowych; przykładowo: w przypadku dostawców biznesowych takich jak Rolls Royce podstawowym modelem biznesowym jest sprzedaż sprzętu takim klientom jak Boeing lub Virgin Atlantic, jednak w tle gromadzone są dane za pomocą zdalnych czujników zainstalowanych w urządzeniach ostrzegających firmę o problemach konserwacyjnych, umożliwiając lepszą obsługę oraz informowanie o kierunkach badania i rozwoju nowych produktów;

- model Broker danych (Data brokers) oparty jest na zarabianiu na zastrzeżonych danych własnych poprzez traktowanie ich jak produktu i sprzedawanie ich innym podmiotom; w tym przypadku dane własne są traktowane jako dane wyjściowe; ten model działania można zaobserwować w firmie badawczej Nielsen, która dostarcza danych i analiz dotyczących zachowań odbiorców;

- model Analiza danych jako usługa (Data analytics as a service) jest powszechnym modelem biznesowym w firmach świadczących usługi analityczne w sferze dużych zbiorów; usługa ta bazuje na przetwarzaniu danych jako usługi, w postaci na przykład przygotowania podsumowania danych, analizy, wizualizacji, porad;

- model Usługi doradcze (Consultancy services) oparty jest na pełnym wykorzystaniu zalet dużych zbiorów danych; wymaga on wiedzy specjalistycznej w zakresie technologii, analizy danych, strategii biznesowej i organizacyjnej, etyki i wielu innych dziedzin;

- model Dostawcy narzędzi (Tools providers) koncentruje się na dostawach nośników pamięci, serwerów i stacji roboczych, skanerów kodów kreskowych, oprogramowania do analizy statystycznej i wizualizacji, oprogramowania bazy danych, czujników zdalnych, technologii szyfrowania i sprzętu sieciowego oraz wielu innych rodzajów sprzętu i oprogramowania.

Inną klasyfikacją modeli biznesowych opartych na danych jest propozycja Levallois - profesora z EMLYON Business School. Wyróżnia on sześć modeli skupionych na danych (tabela 3 ). 
Tabela 3. Klasyfikacja modeli biznesowych opartych na zbieraniu danych wedtug Levallois

\begin{tabular}{|c|c|c|}
\hline Nazwa & Opis & Przykłady \\
\hline $\begin{array}{l}\text { Tworzenie danych, sprzedaż } \\
\text { danych (creating data, selling } \\
\text { data) }\end{array}$ & $\begin{array}{l}\text { Zbieranie, agregowanie, } \\
\text { tworzenie danych, } \\
\text { a następnie ich sprzedawanie }\end{array}$ & $\begin{array}{l}\text { Thomson Reuters, Nielsen, } \\
\text { Twitter, Meteo France, } \\
\text { Orange, ImDB }\end{array}$ \\
\hline $\begin{array}{l}\text { Zbieranie danych, sprzedaż } \\
\text { reklam (gathering data, } \\
\text { selling ads) }\end{array}$ & $\begin{array}{l}\text { Używanie danych } \\
\text { do tworzenia odpowiednich } \\
\text { propozycji reklamowych }\end{array}$ & $\begin{array}{l}\text { Facebook, Yahoo, Microsoft, } \\
\text { Google, Linkedln, Twitter }\end{array}$ \\
\hline $\begin{array}{l}\text { Zbieranie danych, sprzedaż } \\
\text { analityki predykcyjnej } \\
\text { (gathering data, selling } \\
\text { predictive analytics) }\end{array}$ & $\begin{array}{l}\text { Zbieranie danych oraz } \\
\text { prowadzenie analiz } \\
\text { umożliwiających } \\
\text { przewidzenie kolejnych } \\
\text { zachowań klientów, } \\
\text { produktów, usług }\end{array}$ & Tilkee, Visa, PerdPol, InfraTest \\
\hline $\begin{array}{l}\text { Dodawanie goodness danych } \\
\text { do produktów (adding data } \\
\text { goodness to products) }\end{array}$ & $\begin{array}{l}\text { Dodawanie do produktów } \\
\text { dodatkowych możliwości } \\
\text { poprzez analizę danych }\end{array}$ & $\begin{array}{l}\text { Babola, Withings, Nest, Vessyl, } \\
\text { Google }\end{array}$ \\
\hline $\begin{array}{l}\text { Dodawanie goodness danych } \\
\text { do istniejących ustug (adding } \\
\text { data goodness to existing } \\
\text { services) }\end{array}$ & $\begin{array}{l}\text { Dodanie dodatkowych } \\
\text { możliwości do istniejących } \\
\text { usług, powstanie } \\
\text { przyrostowej innowacji }\end{array}$ & $\begin{array}{l}\text { ABN Amro - dodanie } \\
\text { do bankowości internetowej } \\
\text { możliwości porównania } \\
\text { swoich wydatków } \\
\text { z porównywalnymi } \\
\text { gospodarstwami domowymi, } \\
\text { KLM Meet \& Sit - podłączenie } \\
\text { do Facebooka lub LinkedIn } \\
\text { umożliwia wybranie siedzenia } \\
\text { w dowolnym środku } \\
\text { lokomocji koło osoby, którą } \\
\text { chciałoby się spotkać }\end{array}$ \\
\hline $\begin{array}{l}\text { Tworzenie nowych usług } \\
\text { przez eksplorację danych } \\
\text { (creating new services enabled } \\
\text { by data mining) }\end{array}$ & $\begin{array}{l}\text { Poprzez analizowanie, } \\
\text { „kopiowanie danych” } \\
\text { tworzenie nowych ustug oraz } \\
\text { możliwości, w szczególności } \\
\text { w obszarach, które nie } \\
\text { wymagają dużej ilości danych }\end{array}$ & $\begin{array}{l}\text { Uber, Crowd-sourced, } \\
\text { aplikacje takie jak Waze lub } \\
\text { Coyote zastępujące statyczne } \\
\text { systemy nawigacji, MOOCs }\end{array}$ \\
\hline
\end{tabular}

Źródło: opracowanie własne na podstawie Six Business Models Based on Data, www.sli deshare.net/seinecle/six-business-models-based-on-data (dostęp: 26.12.2019).

Przedstawione propozycje klasyfikacji modeli biznesowych opartych na danych powstały w wyniku przeglądu dostępnych w sieci zbiorów informacji. W opinii autorów opracowania nie wyczerpują one jednak całego potencjalnego zbioru tego typu modeli biznesowych. Wśród wymienionych modeli nie ma na przykład modeli zorientowanych na profesjonalne zabezpieczenie, przechowywanie, archiwizowanie, multiplikowanie czy niszczenie danych lub też Internetu rzeczy. Te przedstawione stanowią jedynie forpocztę nowych rozwiązań i nowych propozycji budowania wartości na danych na rosnącym rynku tego typu. 


\section{Modele biznesowe Industry 4.0 oparte na inteligentnym produkcie i ustudze}

Technologia związana z inteligentnymi produktami i usługami otwiera zupełnie nowy typ modeli biznesowych, oparty na rozwiązaniach klasy Big Data, Clouds Computing, inteligentne sensory, czyli takich, które pozwalają oferować innowacyjne usługi i produkty z dodatkowymi funkcjami, dotąd fizycznie nieosiągalnymi.

Ponieważ modele biznesowe oparte na tego typu rozwiązaniach mogą być dla firm ryzykowne, bardzo często ryzyko to jest przenoszone na podmioty zależne, start-upy czy spółki typu spin-off. W ten sposób firma może eksperymentować z nowym modelem biznesowym, nie usuwając starego modelu, wciąż mogącego przynosić dochód.

W tym przypadku aby szukać przewagi, należy spojrzeć na wykorzystanie technologii oraz elementy, które odpowiadają na przykład za ${ }^{28}$ :

- dostarczenie wartości (value delivery) - cechą charakterystyczną tego modelu jest gromadzenie przez inteligentny produkt informacji od klientów oraz ze środowiska o jego pracy i wydajności; w tym modelu wartością jest możliwość przewidywania zachowań produktu przez jego użytkownika; są to zachowania typu: potrzeba aktualizacji, potrzeba regeneracji, dostarczenie części zamiennych i inne działania wspierające utrzymanie i rozwój produktu; w takim modelu istnieje współtworzenie kreacji wartości, w którym biorą udział klienci;

- tworzenie wartości (value creation) - w tym modelu biznesowym możliwe są na przykład działania zorientowane na dostarczanie realnej informacji o produkcie, tworzenie infrastruktury łączącej użytkownika z kluczowymi partnerami tworzącymi produkt czy zmiany w systemie dostarczania lub nawet segmentacji użytkowników;

- przechwytywanie wartości (value capture) - w tym modelu biznesowym przychody tworzone są poprzez działania typu dynamic pricing, pay-per-use czy performance based revenue.

W 1999 roku Goedkoop wraz z innymi badaczami wprowadzili termin product-service systems (PSS) i zdefiniowali go jako „system produktów, usług, sieci graczy i infrastruktury wspierającej, która stale dąży do konkurencyjności, zaspokaja potrzeby klientów i ma mniejszy wpływ na środowisko niż tradycyjne modele biznesowe"29. Na podstawie tej definicji oraz obserwacji można wyróżnić klasyfikacje modeli wskazane w tabeli 4 .

28 D. Ibarra, J. Ganzarain, J.I. Igartua, Business model innovation through Industry 4.0: A review, „Procedia Manufacturing” 2018, no. 22, s. 4-10.

29 M.J. Goedkoop, C.J. Van Halen, H.R. Te Riele, P.J. Rommens, Product service systems, ecological and economic basics, Report for Dutch Ministries of environment (VROM) and economic affairs (EZ), no. 36(1), 1999, s. 1-122. 
Tabela 4. Klasyfikacja modeli biznesowych na podstawie product-service systems

\begin{tabular}{|l|l|}
\hline \multicolumn{1}{|c|}{ Nazwa } & \multicolumn{1}{c|}{ Opis } \\
\hline $\begin{array}{l}\text { Modele biznesowe } \\
\text { zorientowane } \\
\text { na produkt }\end{array}$ & $\begin{array}{l}\text { Celem tego typu modelu jest zapewnienie klientowi konkretnej wartości. } \\
\text { W takim przypadku klient jest wtaścicielem produktu, podczas gdy } \\
\text { dostawca produktu sprzedaje dodatkowe usługi, takie jak konserwacja, } \\
\text { aktualizacje i utrzymanie. }\end{array}$ \\
\hline $\begin{array}{l}\text { Modele biznesowe } \\
\text { zorientowane } \\
\text { na wykorzystanie }\end{array}$ & $\begin{array}{l}\text { Dostawca produktu sprzedaje użyteczność lub dostępność produktów } \\
\text { bez produktu, który nie jest własnością klienta. W porównaniu z prostym } \\
\text { modelem biznesowym wynajmu ten oferuje dodatkowe zalety, takie jak } \\
\text { niższy catkowity koszt posiadania, mniejszy wptyw na środowisko oraz } \\
\text { monitorowanie stanu i analizę oceny żywotności produktu. }\end{array}$ \\
\hline $\begin{array}{l}\text { Modele biznesowe } \\
\text { zorientowane } \\
\text { na wyniki }\end{array}$ & $\begin{array}{l}\text { Dostawca produktu zachowuje własność i sprzedaje wynik lub } \\
\text { możliwości produktu. }\end{array}$ \\
\hline
\end{tabular}

Źródło: opracowanie własne na podstawie: M. Khan, T. Wuest, Upgradable ProductService Systems: Implications for Business Model Components, „Procedia CIRP” 2019, no. 80, s. 768-773, http://doi.org/10.1016/j.procir.2019.01.091

Modele bazujące na idei inteligentnego produktu lub usługi, czyli działające w konwencji smart, zaczynają otaczać nas w coraz szerszym zakresie. Możliwość ich świadczenia zależy przede wszystkim od kompetencji i zasobów firmy wytwarzającej te produkty lub usługi. Kluczowe jest tutaj posiadanie systemów sztucznej inteligencji, wspomnianej technologii Cloud Computing i przede wszystkim platform obsługujących zbiory danych pozyskiwane z tych produktów. Kluczowym graczem w tym obszarze jest obecnie grupa kapitałowa Alphabet.

\section{Modele biznesowe Industry 4.0 oparte na pozornie nieskalowanych dziataniach}

Modele biznesowe oparte na nieskalowalnych działaniach występują przede wszystkim w obszarach, w których mamy do czynienia z masowymi transakcjami. Potencjał technologiczny obszarów Cloud Compuing, Big Data oraz sztucznej inteligencji pozwala obniżyć koszty funkcjonowania systemów obsługowych (koszty transakcyjne) i dotrzeć do grupy demograficznej, do której wcześniej dotarcie byłoby niemożliwe (z powodu wysokich kosztów transakcyjnych). W takiej sytuacji firmy nie muszą dokonywać wyborów na podstawie sprawdzenia możliwości skali. Ponieważ koszty stałe są zazwyczaj bliskie zeru, a koszty zmienne niższe, dzięki nowym technologiom obszary dotąd nierentowne stają się rentowne, zgodnie z zasadą długiego ogona.

W tym podejściu możemy wyróżnić pięć modeli biznesowych - model „uwolnionego" start-upu, model „ponownego" uruchomienia, model platformy, model agregatora, model cyfrowej spółki holdingowej. Szczegółowy opis prezentuje tabela 5. 
Tabela 5. Klasyfikacja modeli biznesowych opartych na pozornie nieskalowanych działaniach

\begin{tabular}{|c|c|c|c|}
\hline Nazwa & Opis & Przykład & $\begin{array}{c}\text { Możliwe strategie } \\
\text { dziatania }\end{array}$ \\
\hline $\begin{array}{l}\text { Model } \\
\text { "uwolnionego" } \\
\text { start-upu (The } \\
\text { unbundled } \\
\text { start-up) }\end{array}$ & $\begin{array}{l}\text { W modelu tym dostrzega się } \\
\text { niszę, która może obejmować } \\
\text { produkt, który nie był wcześniej } \\
\text { oferowany, cechy demograficzne, } \\
\text { które nie są lub nie były } \\
\text { wcześniej doceniane. Model ten } \\
\text { tączy technologię i myślenie } \\
\text { projektowe lub wszystkie } \\
\text { powyższe. Jest to model, } \\
\text { do którego dąży większość firm } \\
\text { fintechowych B2C. }\end{array}$ & $\begin{array}{l}\text { Coinbase, } \\
\text { Lending Club, } \\
\text { Transferwise, } \\
\text { WealthFront, } \\
\text { Sigfig, } \\
\text { Betterment, } \\
\text { etoro, } \\
\text { ZuluTrade, } \\
\text { atoma, APIAX, } \\
\text { unblu }\end{array}$ & $\begin{array}{l}\text { 1. Strategia wzrostu } \\
\text { poprzez uwolnienie } \\
\text { potencjału start-upu. } \\
\text { Rynek z niszowego } \\
\text { staje się dużym } \\
\text { rynkiem. } \\
\text { 2. Strategia wspólnej } \\
\text { marki. Uwolnione } \\
\text { start-upy zaczynają } \\
\text { wiązać wiele } \\
\text { produktów pod } \\
\text { tą samą marką. }\end{array}$ \\
\hline $\begin{array}{l}\text { Model } \\
\text { „ponownego" } \\
\text { uruchomienia } \\
\text { (The rebundled } \\
\text { start-up) }\end{array}$ & $\begin{array}{l}\text { Gdy start-up znajdzie silne } \\
\text { dopasowanie do produktu/ } \\
\text { rynku, zaczyna oferować wiele } \\
\text { produktów w celu zwiększenia } \\
\text { zwrotu z kapitału poprzez } \\
\text { sprzedaż krzyżową i dodatkową } \\
\text { sprzedaż produktów/ustug } \\
\text { dotychczasowym klientom. } \\
\text { W modelu tym skutecznie } \\
\text { przechodzi się z pojedynczej, } \\
\text { nieopakowanej oferty } \\
\text { produktowej do rebundlingu } \\
\text { pełnej usługi, koncentruje się } \\
\text { na obstudze tej samej grupy } \\
\text { demograficznej, nie zajmuje } \\
\text { się masowym marketingiem } \\
\text { i produkcją, ale trzyma się } \\
\text { wąskiego rynku docelowego. }\end{array}$ & \begin{tabular}{|l|} 
Zopa, \\
Transferwise, \\
Revolut
\end{tabular} & $\begin{array}{ll}\text { 1. } & \text { Strategia } \\
\text { koncentracji } \\
\text { na kliencie } \\
\text { i specjalizacja } \\
\text { w danym obszarze } \\
\text { działania. } \\
\text { 2. } \\
\text { Możliwość } \\
\text { zaoferowania } \\
\text { istniejących } \\
\text { produktów/ustug } \\
\text { nowej grupie } \\
\text { docelowej. } \\
\text { 3. Strategia } \\
\text { dywersyfikacji } \\
\text { poprzez włączenie } \\
\text { start-upu do grupy. }\end{array}$ \\
\hline
\end{tabular}


Tabela 5 (cd.)

\begin{tabular}{|c|c|c|c|}
\hline Nazwa & Opis & Przykład & $\begin{array}{c}\text { Możliwe strategie } \\
\text { działania }\end{array}$ \\
\hline $\begin{array}{l}\text { Model } \\
\text { platformy } \\
\text { (The platform } \\
\text { model) }\end{array}$ & $\begin{array}{l}\text { Model funkcjonujący na bazie } \\
\text { wydzielonej platformy dla } \\
\text { start-upów. Ten model nie } \\
\text { pozwala na podejmowanie } \\
\text { szeregu działań o niskiej } \\
\text { wartości dodanej, ale pomaga } \\
\text { wyjść poza zwykte wynajęcie } \\
\text { infrastruktury IT do wynajmu } \\
\text { aplikacji IT. W bankach pomaga } \\
\text { rozłożyć w większości stałe } \\
\text { koszty IT i zgodności na znacznie } \\
\text { większe wolumeny, poprawiając } \\
\text { ekonomię skali. }\end{array}$ & $\begin{array}{l}\text { Wirecard, } \\
\text { Railsbank, } \\
\text { Solaris, } \\
\text { Bancorp }\end{array}$ & $\begin{array}{l}\text { 1. Strategia } \\
\text { koncentracji poprzez } \\
\text { skupienie się } \\
\text { na wybranym rynku/ } \\
\text { regionie/państwie } \\
\text { - możliwości } \\
\text { skalowania } \\
\text { w wybranym } \\
\text { obszarze. } \\
\text { 2. Strategia } \\
\text { koncentracji } \\
\text { poprzez skupienie } \\
\text { się na wybranej } \\
\text { grupie docelowej, } \\
\text { homogenicznej } \\
\text { dla danego } \\
\text { przedsiębiorstwa. }\end{array}$ \\
\hline $\begin{array}{l}\text { Model } \\
\text { agregatora } \\
\text { (The } \\
\text { aggregator } \\
\text { model) }\end{array}$ & $\begin{array}{l}\text { Model agregatora polega na tym, } \\
\text { że firma wykorzystuje swoją } \\
\text { kontrolę nad dystrybucją, aby } \\
\text { zaoferować konsumentowi } \\
\text { odpowiednio wydzielone } \\
\text { ustugi. Model ten skutecznie } \\
\text { wykorzystuje sztuczną } \\
\text { inteligencję i uczenie maszynowe, } \\
\text { aby zrozumieć obszary finansowe } \\
\text { i preferencje klienta oraz } \\
\text { przewidzieć jego potrzeby, aby } \\
\text { móc w odpowiednim czasie } \\
\text { stymulować akcje w serwisie. }\end{array}$ & $\begin{array}{l}\text { Centralway } \\
\text { Numbrs, } \\
\text { M-Shwari, } \\
\text { Starling Bank, } \\
\text { Transferwise } \\
\text { z platformą } \\
\text { Currency } \\
\text { Cloud, } \\
\text { zerwanie N26 } \\
\text { z Wirecard }\end{array}$ & $\begin{array}{l}\text { 1. Strategia integracji } \\
\text { pionowej, } \\
\text { umożliwiająca } \\
\text { perfekcyjną obsługę } \\
\text { klienta. } \\
\text { 2. Strategia } \\
\text { wzmocnienia } \\
\text { ekosystemu poprzez } \\
\text { uzewnętrznienie } \\
\text { efektów sieci. }\end{array}$ \\
\hline $\begin{array}{l}\text { Model } \\
\text { cyfrowej spótki } \\
\text { holdingowej } \\
\text { (The Holding } \\
\text { Company } \\
\text { Model) }\end{array}$ & $\begin{array}{l}\text { Model cyfrowej spółki } \\
\text { holdingowej skupia wokót } \\
\text { spótki matki inne spółki, } \\
\text { które dostarczają określony } \\
\text { produkt/ustugę do danej } \\
\text { grupy demograficznej. Poprzez } \\
\text { standaryzację (np. API) przepływu } \\
\text { cyfrowych danych na poziomie } \\
\text { operacyjnym uzyskuje się } \\
\text { tutaj kosztową przewagę } \\
\text { konkurencyjną. }\end{array}$ & $\begin{array}{l}\text { Ant Financial, } \\
\text { Bank Leumi, } \\
\text { Pepper Bank }\end{array}$ & $\begin{array}{l}\text { 1. Strategia efektu } \\
\text { sieciowego poprzez } \\
\text { dołączanie kolejnych } \\
\text { spółek w cyfrowo } \\
\text { standaryzowany } \\
\text { sposób (API). } \\
\text { 2. Przewaga } \\
\text { konkurencyjna } \\
\text { uzyskiwana } \\
\text { poprzez możliwości } \\
\text { przepływów } \\
\text { kapitałowych w sieci } \\
\text { spółek danej grupy } \\
\text { kapitałowej. }\end{array}$ \\
\hline
\end{tabular}

Źródło: opracowanie własne na podstawie B. Robinson, Five banking business models that work in the digital age paradigm, May 2019, https://pangeagroup.com/articles/ firms-need-business-model-change-not-blockchain/ (dostęp: 29.12.2019). 
Modele biznesowe oparte na nieskalowalnych działaniach są tą grupą modeli, w przypadku których technologie 4.0 wykazują wyjątkowe możliwości poprawy efektywności albo - szerzej - w ogóle są warunkiem pojawienia się efektywności. Technologie 4.0 sprawiają bowiem, że działania, które dotychczas były nieoczywiste, często niemożliwe i nigdy nierozpatrywane, stają się nagle możliwe i wysoce prawdopodobne. Wskazane tutaj modele biznesowe operują przede wszystkim w obszarze start-upów. Takie usytuowanie wynika z ich wysokiego ryzyka. Ryzyko w takiej postaci jest często przenoszone na podmiot zewnętrzny, aby potencjalne koszty braku sukcesu nie obciążały spółki głównej. Część z tych modeli lokuje się w podejściach neoinstytucjonalnych i sieciowych, a niektórym jest już blisko do wybranych fragmentów teorii złożoności, chociażby w postaci systemów samoorganizujących się.

\section{Modele biznesowe Industry 4.0 oparte na strategiach nowoczesnej konkurencji rynkowej}

Czwartą grupą klasyfikacji modeli biznesowych są te bazujące na klasycznym, porterowskim podejściu do konkurencji, ale wzbogaconym o elementy charakterystyczne dla środowiska Industry 4.0, takie jak zwiększenie elastyczności, poszerzenie możliwości modułowej konfiguracji działań, a także zwiększenie zakresu personalizacji produktów i usług.

W tym ujęciu klasyfikacja zaproponowana przez Osterwaldera i Pine'a to propozycja nowoczesnych modeli biznesowych tworzonych przez firmy, które wygrywają konkurencję na rynku.

W publikacji Gorevayi i Khayrullina odnajdziemy pięć typów modeli biznesowych Osterwaldera i Pine’a opisanych właśnie w konwencji wzbogacenia klasycznych narzędzi konkurowania: rozdzielenie modeli biznesowych, długi ogon, platformy wielostronne, rozwiązania darmowe i otwarte modele biznesowe. Szczegółowy opis tych modeli znajduje się w tabeli 6.

Tabela 6. Klasyfikacja modeli biznesowych opartych na strategiach nowoczesnej konkurencji rynkowej

\begin{tabular}{|l|l|l|}
\hline \multicolumn{1}{|c|}{ Nazwa } & \multicolumn{1}{|c|}{ Opis } & \multicolumn{1}{|c|}{ Przykłady firm } \\
\hline $\begin{array}{l}\text { Rozdzielenie modeli } \\
\text { biznesowych } \\
\text { (Separation } \\
\text { of business models) }\end{array}$ & $\begin{array}{l}\text { Model biznesowy zakłada niskokosztowy podziat } \\
\text { modelu w celu stworzenia dobrze funkcjonujących } \\
\text { pojedynczych jednostek lub pojedynczych firm. }\end{array}$ & $\begin{array}{l}\text { ZARA, Compass } \\
\text { Health, } \\
\text { Novosibirsk city } \\
\text { site, RelatelQ }\end{array}$ \\
\hline Długi ogon (Long tail) & $\begin{array}{l}\text { Model biznesowy zakłada koncentrowanie się } \\
\text { na przyciąganiu dużej liczby nabywców produktów } \\
\text { niszowych. }\end{array}$ & $\begin{array}{l}\text { Amazon, Lilu. } \\
\text { com, Drom.ru }\end{array}$ \\
\hline
\end{tabular}


Tabela 6 (cd.)

\begin{tabular}{|l|l|l|}
\hline \multicolumn{1}{|c|}{ Nazwa } & \multicolumn{1}{|c|}{ Opis } & \multicolumn{1}{|c|}{ Przyktady firm } \\
\hline $\begin{array}{l}\text { Platformy } \\
\text { wielostronne } \\
\text { (Multilateral } \\
\text { platforms) }\end{array}$ & $\begin{array}{l}\text { Model biznesowy zakłada dostęp do szerokich } \\
\text { grup klientów poprzez oferowanie dostępu } \\
\text { na bazie platformy. }\end{array}$ & $\begin{array}{l}\text { 2do2go, Kursera, } \\
\text { Eventbright }\end{array}$ \\
\hline $\begin{array}{l}\text { Rozwiązanie darmowe } \\
\text { (Free as a business } \\
\text { model) }\end{array}$ & $\begin{array}{l}\text { Model biznesowy zakłada, że przynajmniej jeden } \\
\text { znaczący segment konsumentów przez dłuższy } \\
\text { czas może korzystać z bezptatnego produktu lub } \\
\text { bezpłatnej ustugi. }\end{array}$ & $\begin{array}{l}\text { 2GIS, Alawar, } \\
\text { Blizzard } \\
\text { Entertainment }\end{array}$ \\
\hline $\begin{array}{l}\text { Otwarte modele } \\
\text { biznesowe (Open } \\
\text { business models) }\end{array}$ & $\begin{array}{l}\text { Model biznesowy zakłada tworzenie i zachowanie } \\
\text { wartości dla klienta, wartości wynikającej } \\
\text { ze współpracy z partnerami zewnętrznymi. } \\
\text { Te modele biznesowe są często używane przez } \\
\text { duże korporacje w celu uzyskania innowacji. }\end{array}$ & $\begin{array}{l}\text { Hackaton, } \\
\text { PayPal, Google }\end{array}$ \\
\hline
\end{tabular}

Źródło: opracowanie własne na podstawie A. Osterwalder, I. Pine, Building of business models, Alpina Publisher Series, Skolkovo, Moscow 2013, s. 288 oraz E. Gorevaya, M. Khayrullina, Evolution of business models: past and present trends, „Procedia Economics and Finance” 2015, no. 27, s. 344-350.

W praktyce w tej grupie modeli biznesowych można wskazać większość modeli z dotychczas obowiązujących klasyfikacji modeli biznesowych. Tak jak wspomniano wcześniej, modele te będą jedynie wspierały i zwiększały ilościowy wymiar oferty produktowej lub usługowej. Odwołują się one bowiem do klasycznego obrazu ekonomii i klasycznych, zasobowych teorii zarządzania. Wyjątkiem jest wskazany w tabeli 6 model długiego ogona, zaprzeczający w pewnym stopniu logice Pareto. Pozwala on bowiem na uzyskiwanie dochodu $\mathrm{z}$ bardzo szerokiej gamy produktów dzięki obniżeniu charakterystycznych dla podejść neoinstytucjonalnych kosztów transakcyjnych.

\section{Typy i rodzaje modeli biznesowych Industry $\mathbf{4 . 0}$ a wybrane nurty ekonomii i nauk o zarządzaniu i cechy modelu biznesowego}

Przedstawione propozycje klasyfikacji modeli biznesowych w czterech grupach są w opinii autorów opracowania interesującymi propozycjami badawczymi. Niemniej by ich analiza była kompletna, w tej części zostanie przedstawione zestawienie typów i rodzajów modeli biznesowych z cechami zdefiniowanego w części drugiej modelu biznesowego charakterystycznego dla Industry 4.0, pod kątem spełniania cech modelu. Celem tego zestawienia jest sprawdzenie, czy rzeczywiście przedstawione klasyfikacje uwzględniają kontekst Industry 4.0.

Drugie zestawienie dotyczyć będzie analizy stopnia uwzględnienia w typach i rodzajach modeli biznesowych wybranych teorii ekonomii i nauk o zarządzaniu. 
Warto przypomnieć, że wybrane nurty ekonomii i nauk o zarządzaniu, zawarte w pierwszej części tego opracowania, opisano w continuum od klasycznych do nowych wyznaczników sposobów gospodarowania. Celem tego zestawienia jest pokazanie, które typy i rodzaje modeli biznesowych i w jakim stopniu spełniają oczekiwania nowych nurtów ekonomii i nauk o zarządzaniu.

Tabela 7. Możliwość spełniania cech modelu biznesowego przez typy lub rodzaje modeli biznesowych

\begin{tabular}{|c|c|c|c|c|c|c|}
\hline Cechy modelu biznesowego & 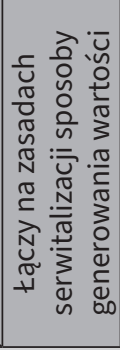 & 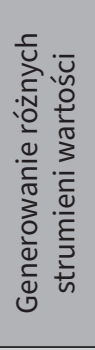 & 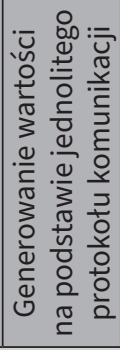 & 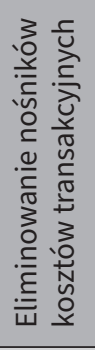 & 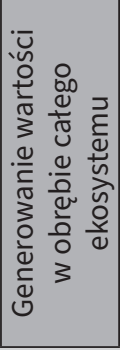 & 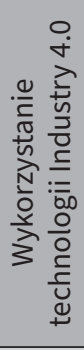 \\
\hline \multicolumn{7}{|c|}{ Modele biznesowe Industry 4.0 oparte na danych } \\
\hline Dane jako ustuga (DaaS) & $\mathrm{X}$ & & & & $\mathrm{X}$ & $X$ \\
\hline Informacje jako usługa (IaaS) & $\mathrm{X}$ & $x$ & $\mathrm{X}$ & $\mathrm{X}$ & $\mathrm{X}$ & $X$ \\
\hline Odpowiedź jako usługa (AssS) & $x$ & $\mathrm{X}$ & $\mathrm{X}$ & & $\mathrm{X}$ & $\mathrm{X}$ \\
\hline $\begin{array}{l}\text { Informowanie o decyzjach } \\
\text { biznesowych (Informing business } \\
\text { decisions) }\end{array}$ & $x$ & & $\mathrm{X}$ & & $\mathrm{X}$ & $\mathrm{X}$ \\
\hline Broker danych (Data brokers) & $\mathrm{X}$ & & $\mathrm{X}$ & $\mathrm{X}$ & $\mathrm{X}$ & $\mathrm{X}$ \\
\hline $\begin{array}{l}\text { Analiza danych jako usługa (Data } \\
\text { analytics as a service) }\end{array}$ & $\mathrm{X}$ & & $\mathrm{X}$ & & $\mathrm{X}$ & $\mathrm{X}$ \\
\hline Ustug doradcze (Consultancy services) & $\mathrm{x}$ & $\mathrm{X}$ & $\mathrm{X}$ & & $\mathrm{X}$ & $\mathrm{x}$ \\
\hline Dostawcy narzędzi (Tools providers) & $\mathrm{X}$ & & $\mathrm{X}$ & & $\mathrm{X}$ & $\mathrm{X}$ \\
\hline $\begin{array}{l}\text { Tworzenie danych, sprzedaż danych } \\
\text { (Creating data, selling data) }\end{array}$ & $\mathrm{X}$ & & $\mathrm{X}$ & $\mathrm{X}$ & $\mathrm{X}$ & $\mathrm{X}$ \\
\hline $\begin{array}{l}\text { Zbieranie danych, sprzedaż reklam } \\
\text { (Gathering data, selling ads) }\end{array}$ & $\mathrm{X}$ & $\mathrm{X}$ & $X$ & & $X$ & $X$ \\
\hline $\begin{array}{l}\text { Zbieranie danych, sprzedaż analityki } \\
\text { predykcyjnej (Gathering data, selling } \\
\text { predictive analytics) }\end{array}$ & $X$ & $X$ & $X$ & $X$ & $X$ & $X$ \\
\hline $\begin{array}{l}\text { Dodawanie goodness danych } \\
\text { do produktów (Adding data goodness } \\
\text { to products) }\end{array}$ & $X$ & $X$ & $X$ & $X$ & $X$ & $X$ \\
\hline $\begin{array}{l}\text { Dodawanie goodness danych } \\
\text { do istniejących ustug (Adding data } \\
\text { goodness to existing services) }\end{array}$ & $X$ & $X$ & $X$ & $X$ & $X$ & $X$ \\
\hline $\begin{array}{l}\text { Tworzenie nowych usług przez } \\
\text { eksplorację danych (Creating new } \\
\text { services enabled by data mining) }\end{array}$ & $X$ & $X$ & $X$ & & $X$ & $X$ \\
\hline
\end{tabular}


Tabela 7 (cd.)

\begin{tabular}{|c|c|c|c|c|c|c|}
\hline Cechy modelu biznesowego & 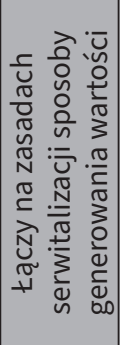 & 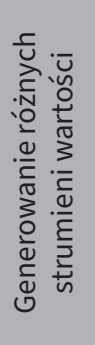 & 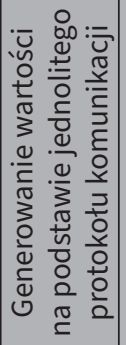 & 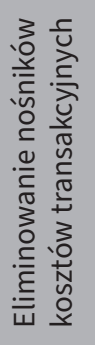 & 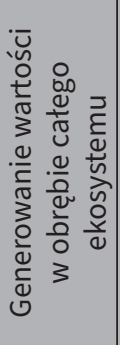 & 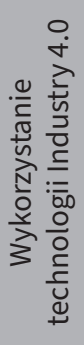 \\
\hline \multicolumn{7}{|c|}{ Modele biznesowe Industry 4.0 oparte na inteligentnym produkcie i usłudze } \\
\hline $\begin{array}{l}\text { Modele biznesowe zorientowane } \\
\text { na produkt }\end{array}$ & $\mathrm{X}$ & $\mathrm{X}$ & $\mathrm{X}$ & $\mathrm{X}$ & $\mathrm{X}$ & $\mathrm{X}$ \\
\hline $\begin{array}{l}\text { Modele biznesowe zorientowane } \\
\text { na wykorzystanie }\end{array}$ & $\mathrm{X}$ & $\mathrm{X}$ & $\mathrm{X}$ & & $\mathrm{X}$ & $\mathrm{X}$ \\
\hline $\begin{array}{l}\text { Modele biznesowe zorientowane } \\
\text { na wyniki }\end{array}$ & $\mathrm{X}$ & $\mathrm{X}$ & $\mathrm{X}$ & & & $\mathrm{X}$ \\
\hline \multicolumn{7}{|c|}{ Modele biznesowe Industry 4.0 oparte na pozornie nieskalowanych działaniach } \\
\hline $\begin{array}{l}\text { Model „uwolnionego” start-upu (The } \\
\text { unbundled start-up) }\end{array}$ & $\mathrm{X}$ & & $\mathrm{X}$ & $\mathrm{x}$ & $\mathrm{X}$ & $\mathrm{X}$ \\
\hline $\begin{array}{l}\text { Model „ponownego” uruchomienia } \\
\text { (The rebundled start-up) }\end{array}$ & $\mathrm{X}$ & $\mathrm{X}$ & $\mathrm{X}$ & $\mathrm{X}$ & $\mathrm{X}$ & $\mathrm{X}$ \\
\hline Model platformy (The platform model) & $\mathrm{X}$ & $\mathrm{X}$ & $\mathrm{X}$ & $\mathrm{X}$ & $\mathrm{X}$ & $\mathrm{X}$ \\
\hline $\begin{array}{l}\text { Model agregatora (The aggregator } \\
\text { model) }\end{array}$ & $\mathrm{X}$ & $\mathrm{X}$ & $\mathrm{X}$ & $\mathrm{X}$ & $\mathrm{X}$ & $\mathrm{X}$ \\
\hline $\begin{array}{l}\text { Model cyfrowej spótki holdingowej } \\
\text { (The Holding Company Model) }\end{array}$ & $\mathrm{X}$ & $\mathrm{X}$ & $\mathrm{X}$ & $\mathrm{X}$ & $\mathrm{X}$ & $\mathrm{X}$ \\
\hline \multicolumn{7}{|c|}{ Modele biznesowe Industry 4.0 oparte na strategiach nowoczesnej konkurencji rynkowej } \\
\hline $\begin{array}{l}\text { Rozdzielenie modeli biznesowych } \\
\text { (Separation of business models) }\end{array}$ & & & $\mathrm{X}$ & & $\mathrm{X}$ & $\mathrm{X}$ \\
\hline Długi ogon (Long tail) & $x$ & $x$ & $x$ & $x$ & $x$ & $x$ \\
\hline $\begin{array}{l}\text { Platformy wielostronne (Multilateral } \\
\text { platforms) }\end{array}$ & $x$ & $x$ & $x$ & $\mathrm{X}$ & $\mathrm{X}$ & $x$ \\
\hline $\begin{array}{l}\text { Rozwiązanie darmowe (Free } \\
\text { as a business model) }\end{array}$ & $x$ & & $x$ & & $x$ & $\mathrm{X}$ \\
\hline $\begin{array}{l}\text { Otwarte modele biznesowe (Open } \\
\text { business models) }\end{array}$ & $\mathrm{X}$ & $\mathrm{X}$ & $\mathrm{X}$ & $\mathrm{X}$ & $\mathrm{X}$ & $\mathrm{X}$ \\
\hline
\end{tabular}

Źródto: opracowanie własne. 
Tabela 8. Powiązanie wybranych nurtów ekonomii i nauk o zarządzaniu z typami i rodzajami modeli biznesowych Industry 4.0

\begin{tabular}{|c|c|c|c|c|c|c|}
\hline \multirow[t]{2}{*}{ Wybrane nurty ekonomii } & \multicolumn{3}{|c|}{$\begin{array}{l}\text { Perspektywa wybranych } \\
\text { nurtów ekonomii }\end{array}$} & \multicolumn{3}{|c|}{$\begin{array}{l}\text { Perspektywa wybranych } \\
\text { nauk o zarządzaniu }\end{array}$} \\
\hline & 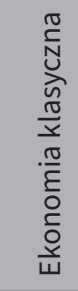 & 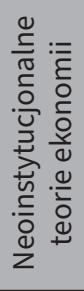 & 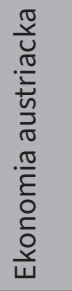 & $\begin{array}{l}0 \\
0 \\
0 \\
0 \\
0 \\
\tilde{N} \\
N \\
\frac{0}{u} \\
\frac{n}{0} \\
\frac{0}{0} \\
0 \\
0\end{array}$ & 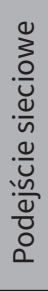 & 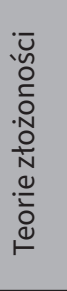 \\
\hline \multicolumn{7}{|c|}{ Modele biznesowe Industry 4.0 oparte na danych } \\
\hline Dane jako usługa (DaaS) & $\mathrm{X}$ & & & $\mathrm{X}$ & $\mathrm{X}$ & $\mathrm{X}$ \\
\hline Informacje jako usługa (IaaS) & $\mathrm{X}$ & $\mathrm{X}$ & $\mathrm{X}$ & $\mathrm{X}$ & $\mathrm{X}$ & \\
\hline Odpowiedź jako usługa (AssS) & $\mathrm{X}$ & $\mathrm{X}$ & $\mathrm{X}$ & $\mathrm{X}$ & $\mathrm{X}$ & $\mathrm{X}$ \\
\hline $\begin{array}{l}\text { Informowanie o decyzjach } \\
\text { biznesowych (Informing business } \\
\text { decisions) }\end{array}$ & $\mathrm{X}$ & $\mathrm{X}$ & $\mathrm{X}$ & $\mathrm{X}$ & $\mathrm{X}$ & \\
\hline Broker danych (Data brokers) & $\mathrm{X}$ & $\mathrm{X}$ & $\mathrm{X}$ & $\mathrm{X}$ & $\mathrm{X}$ & \\
\hline $\begin{array}{l}\text { Analiza danych jako usługa (Data } \\
\text { analytics as a service) }\end{array}$ & $\mathrm{X}$ & $\mathrm{X}$ & $\mathrm{X}$ & $\mathrm{X}$ & $\mathrm{X}$ & $\mathrm{X}$ \\
\hline Usług doradcze (Consultancy services) & $\mathrm{X}$ & $x$ & $\mathrm{X}$ & $\mathrm{X}$ & $\mathrm{X}$ & $\mathrm{X}$ \\
\hline Dostawcy narzędzi (Tools providers) & $X$ & $x$ & $\mathrm{X}$ & $\mathrm{x}$ & & \\
\hline $\begin{array}{l}\text { Tworzenie danych, sprzedaż danych } \\
\text { (Creating data, selling data) }\end{array}$ & $\mathrm{X}$ & $x$ & $\mathrm{X}$ & $\mathrm{X}$ & & \\
\hline $\begin{array}{l}\text { Zbieranie danych, sprzedaż reklam } \\
\text { (Gathering data, selling ads) }\end{array}$ & $\mathrm{X}$ & $\mathrm{X}$ & $\mathrm{X}$ & $\mathrm{X}$ & $\mathrm{X}$ & \\
\hline $\begin{array}{l}\text { Zbieranie danych, sprzedaż analityki } \\
\text { predykcyjnej (Gathering data, selling } \\
\text { predictive analytics) }\end{array}$ & $\mathrm{X}$ & $\mathrm{X}$ & $\mathrm{X}$ & $\mathrm{X}$ & $\mathrm{X}$ & $\mathrm{X}$ \\
\hline $\begin{array}{l}\text { Dodawanie goodness danych } \\
\text { do produktów (Adding data goodness } \\
\text { to products) }\end{array}$ & $\mathrm{X}$ & $\mathrm{X}$ & $\mathrm{X}$ & $\mathrm{X}$ & & \\
\hline $\begin{array}{l}\text { Dodawanie goodness danych } \\
\text { do istniejących ustug (Adding data } \\
\text { goodness to existing services) }\end{array}$ & $\mathrm{X}$ & $x$ & $\mathrm{X}$ & $\mathrm{X}$ & $\mathrm{X}$ & \\
\hline $\begin{array}{l}\text { Tworzenie nowych usług przez } \\
\text { eksplorację danych (Creating new } \\
\text { services enabled by data mining) }\end{array}$ & $\mathrm{X}$ & $x$ & $\mathrm{X}$ & $\mathrm{X}$ & $x$ & $\mathrm{X}$ \\
\hline \multicolumn{7}{|c|}{ Modele biznesowe Industry 4.0 oparte na inteligentnym produkcie i usłudze } \\
\hline $\begin{array}{l}\text { Modele biznesowe zorientowane } \\
\text { na produkt }\end{array}$ & $\mathrm{X}$ & & & $\mathrm{X}$ & & \\
\hline $\begin{array}{l}\text { Modele biznesowe zorientowane } \\
\text { na wykorzystanie }\end{array}$ & $\mathrm{X}$ & $\mathrm{X}$ & & $\mathrm{X}$ & $\mathrm{X}$ & \\
\hline $\begin{array}{l}\text { Modele biznesowe zorientowane } \\
\text { na wyniki }\end{array}$ & $\mathrm{X}$ & & & $\mathrm{X}$ & & \\
\hline
\end{tabular}


Tabela 8 (cd.)

\begin{tabular}{|c|c|c|c|c|c|c|}
\hline \multirow[t]{2}{*}{ Wybrane nurty ekonomii } & \multicolumn{3}{|c|}{$\begin{array}{l}\text { Perspektywa wybranych } \\
\text { nurtów ekonomii }\end{array}$} & \multicolumn{3}{|c|}{$\begin{array}{l}\text { Perspektywa wybranych } \\
\text { nauk o zarządzaniu }\end{array}$} \\
\hline & 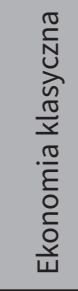 & 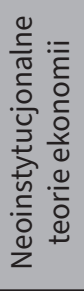 & 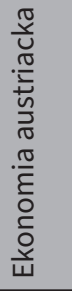 & $\begin{array}{l}0 \\
3 \\
0 \\
0 \\
0 \\
N \\
N \\
\frac{0}{n} \\
\frac{n}{0} \\
\frac{n}{0} \\
0 \\
0\end{array}$ & 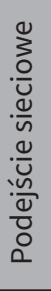 & 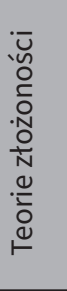 \\
\hline \multicolumn{7}{|c|}{ Modele biznesowe Industry 4.0 oparte na pozornie nieskalowanych działaniach } \\
\hline $\begin{array}{l}\text { Model „uwolnionego" start-upu (The } \\
\text { unbundled start-up) }\end{array}$ & $\mathrm{X}$ & $\mathrm{X}$ & & $x$ & $\mathrm{X}$ & \\
\hline $\begin{array}{l}\text { Model „ponownego" uruchomienia } \\
\text { (The rebundled start-up) }\end{array}$ & $\mathrm{X}$ & $\mathrm{X}$ & & $\mathrm{X}$ & $\mathrm{X}$ & \\
\hline Model platformy (The platform model) & $\mathrm{X}$ & $\mathrm{X}$ & & $\mathrm{X}$ & $\mathrm{X}$ & $\mathrm{X}$ \\
\hline $\begin{array}{l}\text { Model agregatora (The aggregator } \\
\text { model) }\end{array}$ & $\mathrm{X}$ & $\mathrm{X}$ & & $\mathrm{X}$ & $\mathrm{X}$ & \\
\hline $\begin{array}{l}\text { Model cyfrowej spótki holdingowej } \\
\text { (The Holding Company Model) }\end{array}$ & $\mathrm{X}$ & $\mathrm{X}$ & & $\mathrm{X}$ & $\mathrm{X}$ & $\mathrm{X}$ \\
\hline \multicolumn{7}{|c|}{ Modele biznesowe Industry 4.0 oparte na strategiach nowoczesnej konkurencji rynkowej } \\
\hline $\begin{array}{l}\text { Rozdzielenie modeli biznesowych } \\
\text { (Separation of business models) }\end{array}$ & $\mathrm{X}$ & $\mathrm{X}$ & $\mathrm{X}$ & $\mathrm{X}$ & & \\
\hline Długi ogon (Long tail) & $\mathrm{X}$ & $\mathrm{X}$ & & $\mathrm{X}$ & $\mathrm{X}$ & $\mathrm{X}$ \\
\hline $\begin{array}{l}\text { Platformy wielostronne (Multilateral } \\
\text { platforms) }\end{array}$ & $\mathrm{X}$ & $\mathrm{X}$ & & $\mathrm{X}$ & $\mathrm{X}$ & $\mathrm{X}$ \\
\hline $\begin{array}{l}\text { Rozwiązanie darmowe (Free } \\
\text { as a business model) }\end{array}$ & $\mathrm{X}$ & $\mathrm{X}$ & & $\mathrm{X}$ & $\mathrm{X}$ & \\
\hline $\begin{array}{l}\text { Otwarte modele biznesowe (Open } \\
\text { business models) }\end{array}$ & $\mathrm{X}$ & $\mathrm{X}$ & $\mathrm{X}$ & $\mathrm{X}$ & $x$ & $X$ \\
\hline
\end{tabular}

Źródto: opracowanie własne.

Analiza zestawienia zamieszczonego w tabeli 7 wskazuje, że wszystkie modele biznesowe mają przynajmniej jedną cechę modelu 4.0. Do modeli biznesowych spełniających w najwyższym stopniu wymagania definicji modelu biznesowego 4.0 należą modele z grupy opartych na pozornie nieskalowalnych działaniach i strategiach nowoczesnej konkurencji.

Analiza zestawienia zamieszczonego w tabeli 8 wskazuje z kolei, że wszystkie modele biznesowe lokują się we wskazanych nurtach ekonomii i nauk o zarządzaniu, przy czym najczęściej są to jednak klasyczne nurty ekonomii i zasobowe teorie zarządzania. Do typów i rodzajów modeli biznesowych mających cechy neoinstytucjonalnych nurtów ekonomii i potencjał sieciowy należą modele, które materializują się przede wszystkim w postaci transakcji, w mniejszym zakresie klasycznej optymalizacji zasobowej. Dlatego też potencjału sieciowego nie wykazuje część modeli opartych na inteligentnym produkcie lub usłudze. Najmniej modeli 
biznesowych można wstępnie lokować w obszarze, w którym byłaby możliwość wykorzystania ontologii ekonomii austriackiej. Są to przede wszystkim modele biznesowe oparte na danych i wybrane modele nowej konkurencji. Z kolei potencjał teorii złożoności dostrzec można przede wszystkim w modelach opartych na danych i na nowych sposobach konkurencji.

\section{Podsumowanie}

Przedstawione propozycje klasyfikacji modeli biznesowych, charakterystyczne dla Industry 4.0, są próbą pewnej taksonomii. Industry 4.0 jest jeszcze w fazie inkubacji. Są to dopiero pierwsze próby uogólnień. Warto podkreślić, że większość propozycji dotyczy klasycznych archetypów ekonomii i klasycznych, zasobowych ujęć zarządzania (tabele 7 i 8). Wiele jest już jednak prób wykorzystania możliwości biznesowego „modelowania” organizacji rozumianej jako zbiór kontraktów czy organizacji opisanej wymiarami sieci organizacyjnej lub międzyorganizacyjnej. Najmniej rozwiązań dotyczy ekonomii austriackiej i teorii złożoności. To prawdopodobnie dopiero przyszłość modeli biznesowych klasy Industry 4.0.

Ciekawą propozycją uogólnienia zawartych w tym opracowaniu rozważań jest próba zbudowania archetypów modeli biznesowych dla Industry 4.0. Autorzy publikacji Archetypes for Industry 4.0 Business Model Innovations wyróżnili trzy superarchetypy i dziesięć subarchetypów modeli biznesowych. Z tej propozycji wynika, że innowacje 4.0 mogą być wprowadzone jako superarchetypy: wokół nowych procesów, w postaci serwitalizacji wokół nowych produktów i w postaci wiedzy specjalistycznej jako usługi. Tabela 9 zawiera przegląd podstawowych archetypów i subarchetypów modeli biznesowych.

Tabela 9. Archetypy innowacji w modelu biznesowym Industry 4.0

\begin{tabular}{|c|c|c|c|c|c|c|}
\hline Super archetyp & \multicolumn{6}{|c|}{ Subarchetypy } \\
\hline Nowe procesy & \multicolumn{2}{|c|}{ Crowd sourced innovation } & \multicolumn{2}{|c|}{\begin{tabular}{|l|} 
Produkcja jako \\
ustuga
\end{tabular}} & \multicolumn{2}{|c|}{ Masowa personalizacja } \\
\hline Serwitalizacja & \multicolumn{2}{|c|}{ Długotrwałe partnerstwa } & \multicolumn{2}{|c|}{$\begin{array}{l}\text { Produkt jako } \\
\text { ustuga }\end{array}$} & \multicolumn{2}{|c|}{ Wynik jako usługa } \\
\hline $\begin{array}{l}\text { Ekspertyza jako } \\
\text { ustuga }\end{array}$ & $\begin{array}{l}\text { Doradztwo } \\
\text { związane } \\
\text { z produktem }\end{array}$ & $\begin{array}{l}\text { Doradz } \\
\text { związa } \\
\text { z proce }\end{array}$ & & $\begin{array}{l}\text { Platfo } \\
\text { broke }\end{array}$ & & Platformy loT \\
\hline
\end{tabular}

Źródło: J. Weking i wsp., Archetypes for Industry 4.0 business model innovations, Twentyfourth Americas Conference on Information Systems (AMCIS 2018), New Orleans 2018.

Przedstawiona w tabeli 9 propozycja w znacznym stopniu obejmuje wymienione w opracowaniu klasyfikacje modeli biznesowych Industry 4.0: 
- oparte na danych;

- oparte na inteligentnym produkcie i usłudze;

- oparte na pozornie nieskalowanych działaniach;

- oparte na strategiach nowoczesnej konkurencji rynkowej.

Wskazane w opracowaniu propozycje taksonomii modeli biznesowych w obszarze wdrożeń technologii Industry 4.0 są w opinii autorów propozycją pozwalającą dokonywać wyborów strategicznych przez firmy wchodzące w przemysł 4.0, ale też mogą być w pewnym stopniu uznane za podstawę prowadzenia dalszych badań nad rozwojem wiedzy w zakresie modeli biznesowych dla technologii 4.0, szczególnie w kontekście poszukiwania kolejnych modeli dla rozwiązań sieciowych i wybranych teorii z grupy teorii złożoności.

\section{Bibliografia}

Barton D., Court D., Three keys to building a data-driven strategy, www.mckinsey.com/business-functions/mckinsey-digital/our-insights/three-keys-to-building-a-data-driven-strategy (dostęp: 22.12.2019).

Bauer W., Hämmerle M., Schlund S., Vocke C., Transforming to a hyper-connected society and economy - towards an „Industry 4.0”, „Procedia Manufacturing” 2015, no. 3, s. 417-424.

Boston Dynamics, www.bostondynamics.com (dostęp: 20.12.2019).

Burmeister C., Lüttgens D., Piller F.T., Business model innovation for Industrie 4.0: why the „Industrial Internet” mandates a new perspective on innovation, „Die Unternehmung” 2016, vol. 70(2), s. 124-152.

Chesbro G., Open business model. IP-Management, Generation, 2008.

Czarnecki L., Model DNA firmy, „Monografie i Opracowania Uniwersytetu Ekonomicznego we Wrocławiu" 2015, nr 252.

Czarnecki M., Rozwój organizacyjny a problemy wzrostu przedsiębiorstw, Wydawnictwo Difin, Warszawa 2016.

Dudycz H., Mapa pojęćjako wizualna reprezentacja wiedzy ekonomicznej, „Monografie i Opracowania Uniwersytetu Ekonomicznego we Wrocławiu” 2013, nr 229.

Exploring big data business models \& the winning value propositions behind them, www.businessmodelsinc.com/big-data-business-models/ (dostęp: 29.12.2019).

Falencikowski T., Istota chmury wartości - zatożenia podstawowe, „Prace Naukowe Wałbrzyskiej Wyższej Szkoły Zarządzania i Przedsiębiorczości” 2015, nr 32, s. 121-129.

Frank A.G., Mendes G.H., Ayala N.F., Ghezzi A., Servitization and Industry 4.0 convergence in the digital transformation of product firms: A business model innovation perspective, „Technological Forecasting and Social Change" 2019, no. 141, s. 341-351.

Goedkoop M.J., Van Halen C.J., Te Riele H.R., Rommens P.J., Product service systems, ecological and economic basics, Report for Dutch Ministries of environment (VROM) and economic affairs (EZ), no. 36(1), 1999, s. 1-122.

Gorevaya E., Khayrullina M., Evolution of business models: past and present trends, „Procedia Economics and Finance" 2015, no. 27, s. 344-350.

Härting R.C., Reichstein C., Schad M., Potentials of Digital Business Models - Empirical investigation of data driven impacts in industry, „Procedia Computer Science” 2018, no. 126, s. 1495-1506. 
Hecklau F., Galeitzke M., Flachs S., Kohl H., Holistic approach for human resource management in Industry 4.0, „Procedia CIRP” 2016, no. 54, s. 1-6.

Ibarra D., Ganzarain J., Igartua J.I., Business model innovation through Industry 4.0: A review, „Procedia Manufacturing” 2018, no. 22, s. 4-10.

Jacobides M.G., Cennamo C., Gawer A., Towards a theory of ecosystems, „Strategic Management Journal" 2018, vol. 39(8), s. 2255-2276.

Kagermann H., Helbig J., Hellinger A., Wahlster W., Recommendations for implementing the strategic initiative INDUSTRIE 4.0: Securing the future of German manufacturing industry, final report of the Industrie 4.0 Working Group, Forschungsunion, 2013.

Khan M., Wuest T., Upgradable Product-Service Systems: Implications for Business Model Components, „Procedia CIRP” 2019, no. 80, s. 768-773, http://doi.org/10.1016/j.procir.2019.01.091

Markides C., The new business model: strategy of painless innovation The new business model: strategy of painless innovation, Alpina Publisher, Moscow 2010.

Mercier-Laurent E., Innovation ecosystems, John Wiley \& Sons, New York 2013.

Möller K., Halinen A., Managing business and innovation networks - From strategic nets to business fields and ecosystems, „Industrial Marketing Management” 2017, no. 67, s. 5-22.

Niemczyk J., Trzaska R., Borowski K., Karolczak P., Scalability 4.0 as Economic Rent in Industry 4.0, „Transformations in Business \& Economics” 2019, no. 18, s. 824-839.

Osterwalder A., Pine I., Building of business models, Alpina Publisher Series, Skolkovo, Moscow 2013.

Porter M.E., Heppelmann J.E., How smart, connected products are transforming competition, „Harvard Business Review” 2014, vol. 92(11), s. 64-88.

Robinson B., Five banking business models that work in the digital age paradigm, May 2019, https://pangeagroup.com/articles/firms-need-business-model-change-not-blockchain/ (dostęp: 29.12.2019).

Rokita J., Dziubińska A., Systemy złożone w zarządzaniu, „Prace Naukowe Uniwersytetu Ekonomicznego w Katowicach", Wydawnictwo Uniwersytetu Ekonomicznego, Katowice 2016.

Schmidt R., Möhring M., Härting R.C., Reichstein C., Neumaier P., Jozinović P., Industry 4.0 - potentials for creating smart products: empirical research results, [w:] International Conference on Business Information Systems, Springer, Cham 2015, s. 16-27.

Schroeder R., Big data business models: Challenges and opportunities, „Cogent Social Sciences” 2016, vol. 2(1), s. 1-15.

Six Business Models Based on Data, www.slideshare.net/seinecle/six-business-models-based-on-data (dostęp: 26.12.2019).

Slywotzky A.J., Migration values. What will happen to your business the day after tomorrow, Mann, Ivanov and Ferber, Moscow 2006.

Weking J., Stöcker M., Kowalkiewicz M., Böhm M., Krcmar H., Archetypes for Industry 4.0 business model innovations, Twenty-fourth Americas Conference on Information Systems (AMCIS 2018), New Orleans 2018. 


\section{Streszczenie}

Celem badań, których wyniki zostały przedstawione w opracowaniu, było sprawdzenie - na podstawie analizy piśmiennictwa w obszarze nauk o zarządzaniu - propozycji wyodrębnienia rodzajów lub typów modeli biznesowych właściwych do rozwiązań wymuszonych przez zmiany technologiczne, techniczne, ekonomiczne i społeczne związane z rewolucją przemysłową, potocznie określaną mianem 4.0. Należy przy tym dodać, że przyjętą perspektywą analityczną jest spojrzenie z punktu widzenia przedsiębiorstwa wdrażającego rozwiązania Industry 4.0 lub powstającego całkowicie w warunkach nowej gospodarki.

W opracowaniu wyodrębniono cztery podstawowe części. Pierwsza zawiera przyjętą przez autorów, na podstawie przeglądu aktualnego piśmiennictwa, propozycję ujmowania Industry $4.0 \mathrm{z}$ perspektyw ekonomii i nauk o zarządzaniu. Druga część przedstawia przyjętą w pracy propozycję definicji modelu biznesowego, właściwą w opinii autorów do zmian generowanych przez Industry 4.0. Trzecia część zawiera przegląd wyników badań obecnych w literaturze przedmiotu, dotyczących rodzajów lub modeli biznesowych odpowiadających zmianom 4.0. Czwarta część to próba zweryfikowania wyróżnionych modeli biznesowych z perspektywy cech modelu biznesowego 4.0 i wybranych nurtów ekonomii i nauk o zarządzaniu, bliskich konstrukcjom Industry 4.0. Rozważania zawarte w opracowaniu oscylują wokół problemu badawczego sprowadzającego się do poszukiwania odpowiedzi na pytanie, czy Industry 4.0 generuje zupełnie nowe rodzaje i typy modeli biznesowych, czy też tylko adaptuje do nowych warunków istniejące modele biznesowe.

Słowa kluczowe: zarządzanie, zarządzanie strategiczne, model biznesowy, Industry 4.0

\section{Business models classification in Industry 4.0}

\section{Abstract}

The purpose of the research, the results of which are presented here, was to check, based on the analysis of the literature in the field of management science, proposals to identify the types of business models appropriate for solutions forced by technological, technical, economic and social changes related to the industrial revolution commonly referred to as 4.0. It should be added that the adopted analytical perspective is the perspective from the point of view of an enterprise implementing solutions 4.0 or arising entirely in the conditions of a new economy.

The chapter has three basic parts. The first part contains the proposal adopted by the authors, based on a review of current literature, to include Industry 4.0 in economic and management perspectives. The second part contains the proposal for the definition of the business model adopted in the chapter, which in the authors' opinion is appropriate for the changes generated by Industry 4.0. The third part is the results of the review of the results of research present in the literature on the types or business models corresponding to changes 4.0.

The considerations contained in the chapter revolve around a research problem boiling down to seeking the answer to the question whether Industry 4.0 generates completely new types of business models, or is it just adapting existing business models to new conditions?

Keywords: management, strategic management, business model, Industry 4.0 